\title{
Deformation recorded in polyhalite from evaporite detachments revealed by ${ }^{40} \mathrm{Ar} /{ }^{39} \mathrm{Ar}$ dating
}

Richards, Lachlan. ${ }^{1}$, Jourdan, Fred. ${ }^{2}$, Collins, Alan Stephen. ${ }^{1}$, King, Rosalind Clare. ${ }^{1}$

${ }^{1}$ Centre for Tectonics, Resources and Exploration (TRaX), Department of Earth \& Environmental Sciences, The University

5 of Adelaide, SA 5005, Australia

${ }^{2}$ School of Earth and Planetary Sciences \& JDL Centre, Curtin University, Perth WA 6845, Australia

Correspondence to: Lachlan Richards (lachlan.richards@aberdeen.ac.uk)

\section{Abstract}

The Salt Range Formation is an extensive evaporite formation in northern Pakistan that has acted as the primary detachment

10 accommodating Himalayan orogenic deformation from the north. This rheologically weak formation forms a mylonite in the Khewra mines, where it accommodates approximate $40 \mathrm{~km}$ displacement and is comprised of intercalated halite and potash salts and gypsiferous marls. Polyhalite $\left[\mathrm{K}_{2} \mathrm{Ca}_{2} \mathrm{Mg}\left(\mathrm{SO}_{4}\right) 4 \cdot 2 \mathrm{H}_{2} \mathrm{O}\right]$ grains taken from potash marl and crystalline halite samples are used as geochronometers to date the formation and identify the closure temperature of the mineral polyhalite using the ${ }^{40} \mathrm{Ar} /{ }^{39} \mathrm{Ar}$ step heating method. The diffusion characteristics measured for two samples of polyhalite are diffusivity $\left(\mathrm{D}_{0}\right)$,

15 activation energy (Ea), and $\%{ }^{39} \mathrm{Ar}$. These values correspond to a closure temperature of ca. 281 and $296{ }^{\circ} \mathrm{C}$ for a cooling rate of $10{ }^{\circ} \mathrm{C} / \mathrm{Ma} .{ }^{40} \mathrm{Ar} /{ }^{39} \mathrm{Ar}$ age results for both samples did not return any reliable crystallization age. This is not unexpected as polyhalite is prone to ${ }^{40} \mathrm{Ar}^{*}$ diffusion loss and the evaporites have experienced numerous phases of deformation resetting the closed K/Ar system. An oldest minimum heating step age of $514 \pm 3$ Ma from sample 06-3.1 corresponds relatively well to the established early Cambrian age of the formation. Samples 05-P2 and 05-W2 have apparent step ages and represent a

20 deformation event that partially reset the K/Ar system based on oldest significant ages between ca. $381 \mathrm{Ma}$ and $415 \mathrm{Ma}$. We interpret the youngest apparent step ages, between ca. $286 \mathrm{Ma}$ and $292 \mathrm{Ma}$, to represent the maximum age of deformationinduced recrystallisation. Both the youngest and oldest apparent step ages for Samples 05-P2 and 05-W2 occur within the time of a major unconformity in the area. These dates may reflect partial resetting of the K/Ar system from meteoric water infiltration and recrystallisation during this non-depositional time. Else, they may result from mixing of Ar derived by

25 radiogenic decay after Cambrian precipitation with partially reset Ar from pervasive Cenozoic deformation and physical recrystallisation.

\section{Introduction}

Diagenesis of evaporites from marine brines is initiated by the precipitation of specific minerals in sequence based on the composition of the parent brine with increasing salinity. Initially carbonates $\left[\mathrm{CaCO}_{3}\right]$ precipitate, followed by gypsum

$30\left[\mathrm{CaSO}_{4}\right]$ in penesaline brines, halite in supersaline brines and eventually bittern salts (K-Mg-salts) (Warren, 2006). Bittern 
https://doi.org/10.5194/gchron-2021-16

Preprint. Discussion started: 28 May 2021

(c) Author(s) 2021. CC BY 4.0 License.

(c) (i)

salt precipitation is a complex paragenetic process whereby the evolving brine chemistry and precipitate solubility define the terminal assemblage with any hydrological influx causing back reactions and alteration during or post lithification (Hardie, 1984 \& 1990; Warren, 2006). The sedimentation of laterally extensive and thick evaporite deposits require hyper-arid climates with extreme evaporation, tectonically isolated basins with optimal hydrogeology to restrict brine refreshing and dissolution (Warren, 2006). An ancient example of a thick, laterally extensive evaporite containing significant quantities of bittern salts is the Salt Range Formation in northern Pakistan (Jaumé and Lillie, 1988; Richards et al. 2015). It is comprised of a thick crystalline halite intercalated with bands of potash marl overlain by a gypsiferous marl and gypsum-dolomite (Ghazi et al., 2012). The Salt Range Formation acts as a detachment horizon for the distal foreland fold-thrust belt of the South Potwar Basin, which is a being driven by Himalayan orogenic deformation (far field stresses) and gravity gliding (near 40 field stresses) (Jaumé and Lillie 1988, Davis and Lillie 1994, Richards et al. 2015). Ages of the Salt Range Formation are poorly constrained with trilobite trace fossils in the directly overlying Khewra Sandstone establishing the upper boundary as early Cambrian and the Precambrian metasedimentary basement rocks of the Indian Shield forming the lower boundary (Gee, 1989; Khan et al., 1986; Schindewolf and Seilacher, 1955).

Polyhalite is a bittern salt, forming as both a primary precipitate but more commonly as a diagenetic secondary phase during

45 back reaction of gypsum with a K-Mg-SO ${ }_{4}$ brine (Hardie, 1990; Warren, 2006). It is one of the primary potash (K-bearing) salts applicable to $\mathrm{K} / \mathrm{Ar}$, or its derivative, ${ }^{40} \mathrm{Ar} /{ }^{39} \mathrm{Ar}$ geochronology (e.g., Leitner et al. 2014). Since the initial investigation of ${ }^{40} \mathrm{Ar}$ abundance in K-bearing evaporite minerals (Aldrich and Nier, 1948) many studies have used a range of minerals as geochronometers (Reiners et al., 2017). Extensive work on Miocene samples of polyhalite, kainite, and in particular langbeinite from the Carpathian foredeep basin to determine depositional age, of primary langbeinite, and recrystallisation

50 ages after major tectonic events (Leost et al., 2001; Wójtowicz et al. 2003) using both $\mathrm{K}-\mathrm{Ar}$ and ${ }^{40} \mathrm{Ar} /{ }^{39} \mathrm{Ar}$ radioisotopic dating. Similarly, polyhalite and langbeinite from the Castile and Salado Formations in southeast New Mexico, respectively, have been used with some success yielding ages of deposition and deformation (Brookins et al., 1980; Renne et al., 2001). While langbeinite is a more robust potash mineral, being less susceptible to later alteration and Ar diffusion, polyhalite is potentially a useful geochronometer with dates recovered from diagenetic and deformed polyhalite samples from the 55 Haselgebirge Formation, a major evaporite detachment in the Northern Calcareous Alps (Leitner et al., 2013).

In this study, we use the ${ }^{40} \mathrm{Ar} /{ }^{39} \mathrm{Ar}$ step heating process in an attempt to date grains of polyhalite from two samples from the Khewra Mines in the Salt Range, Pakistan. We also establish the Ar diffusion parameters and associated closure temperature of polyhalite in the K/Ar isotopic system. Though these results are semi-quantitative, they are contextualised with the structural history of the host formation to form a speculative interpretation of deformation history. 
https://doi.org/10.5194/gchron-2021-16

Preprint. Discussion started: 28 May 2021

(c) Author(s) 2021. CC BY 4.0 License.

(c) (i)

60 2. Geological Background (stratigraphy- composition - samples)

\subsection{Location}

Northward convergence of the Indian plate with the Eurasian plates in the northern regions of Pakistan and India has resulted in the classic continent-continent collision deformation structures on display in this region (Fig. 1A) (Jaswal et al., 1997). Continued convergence and crustal shortening since the late Cretaceous saw the overthrusting of parts of the Indian passive

65 margin over the Indian craton to the south, initiating and migrating new faults southward (Powell and Conaghan, 1973; Molnar and Tapponnier, 1977). The Main Mantle Thrust (MMT) separates the High Himalayas from the Lesser Himalaya to the south, which is itself separated from the Siwalik Hills and North Potwar Deformation Zone (NPDZ) by the Main Boundary Thrust (MBT) in northern Pakistan (Jaswal et al., 1997; Powell and Tapponnier, 1973) (Fig 1). 


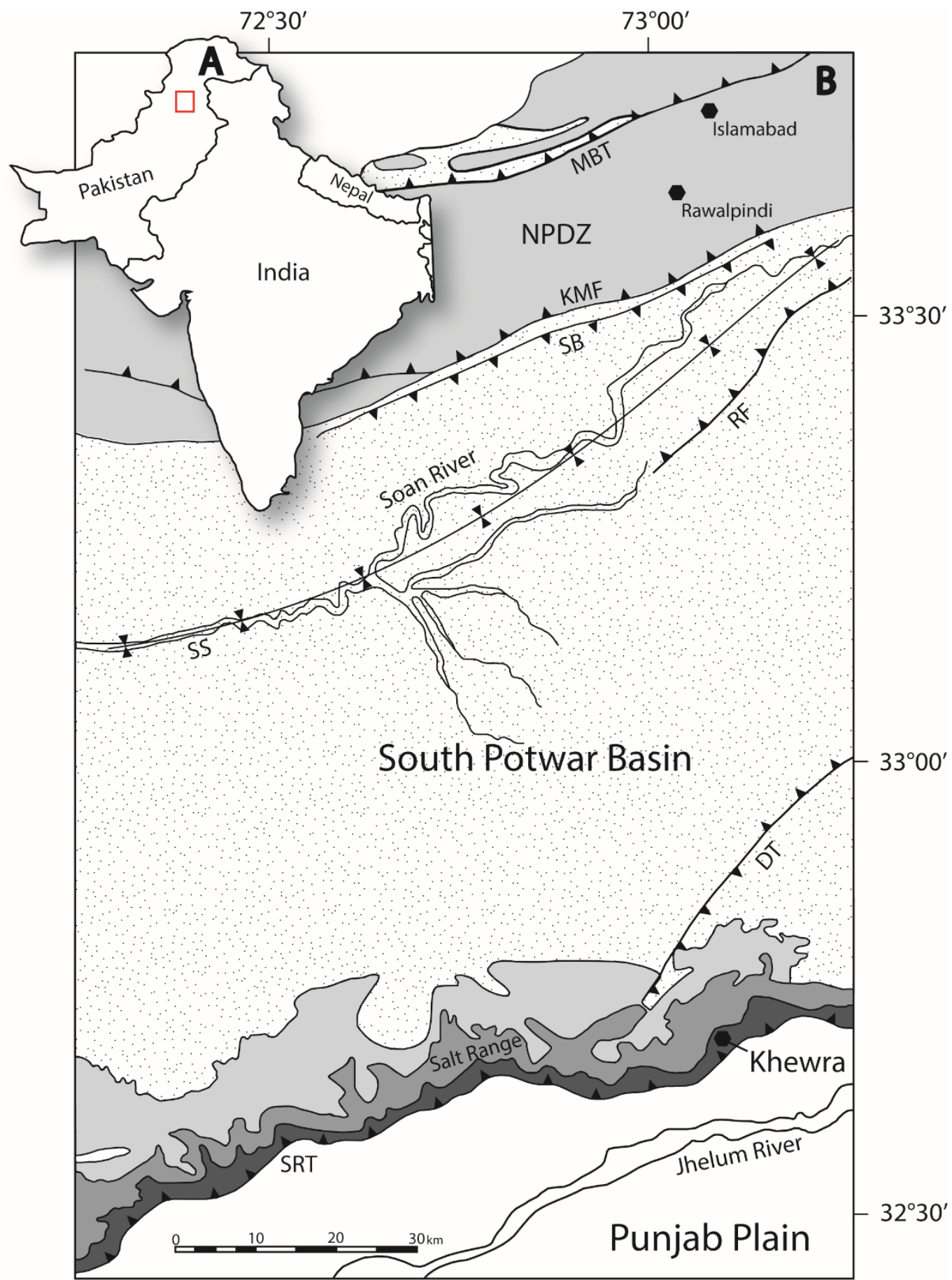

Fig. 1. A) Location map of the study area. B) Geological map of the eastern Salt Range and Potwar Plateau. MBT = Main Boundary Thrust, NPDZ = North Potwar Deformation Zone, KMF = Khari Murat Fault, SB = Soan Backthrust, SS = Soan Syncline, RF = Riwat Fault, DT = Domeli Thrust, SRT = Salt Range Thrust. (after Richards et al., 2015) 
https://doi.org/10.5194/gchron-2021-16

Preprint. Discussion started: 28 May 2021

(c) Author(s) 2021. CC BY 4.0 License.

(c) (i)

75 Further south, the NPDZ is separated from sedimentary rocks of the South Potwar Basin, also referred to as the Potwar Plateau, by the Khari Murat Fault (KMF) and Soan Backthrust (SB) in Fig. 1. The Potwar Plateau is a distal foreland foldthrust-belt (FTB) that is thrust southward over a thick evaporite detachment, the Salt Range Formation (Davis and Lillie, 1994; Jaume and Lillie, 1988). At the southern extent of the Potwar Plateau, the Salt Range Thrust (SRT) has displaced Precambrian to Eocene sedimentary rocks over Quaternary sediments of the Punjab Plain (Jaswal, 1997; Yeats et al., 1984).

80 The SRT has allowed the southward transposition of nearly undeformed overburden and resulted in a critical taper wedge with a frontal angle of $<1^{\circ}$ (Jaume and Lillie, 1988). The Salt Range forms the southerly expression of the Himalayan orogeny. The range results from thrust ramping over a pre-existing basement normal fault, driven by a combination of both near (gravity gliding) and far field (continent continent collision) stresses (Davis and Lillie, 1994; Jaume and Lillie, 1988; Lillie et al., 1987). Recent seismic activity indicates that the Salt Range Thrust is active, and moves at a rate of $3 \mathrm{~mm} / \mathrm{yr}$,

85 though slip is typically aseismic owing to the rheological weakness of the basal evaporites (Haq et al., 2013; Satyabala et al., 2012).

\subsection{Stratigraphy}

The oldest rocks in this region are the Precambrian crystalline basement of the Indian Shield with the nearest exposure in the Kirana Hills, $80 \mathrm{~km}$ south of the Salt Range (Fig. 2A) (Gee, 1989). These are unconformably overlain by evaporites of the

90 Salt Range Formation that formed in a restricted basin environment (Jaswal et al., 1997). The Salt Range Formation has three members: the Billianwala Salt, which is comprised of massive crystalline halite and sometimes banded with layers of potash marl, the Sahwal Marl, which is a red marl with some gypsum, and the Bandarkas Gypsum, which is a red marl containing both crystalline and non-crystalline folded and sheared gypsum (Fig. 2B)(Richards et al., 2015). 


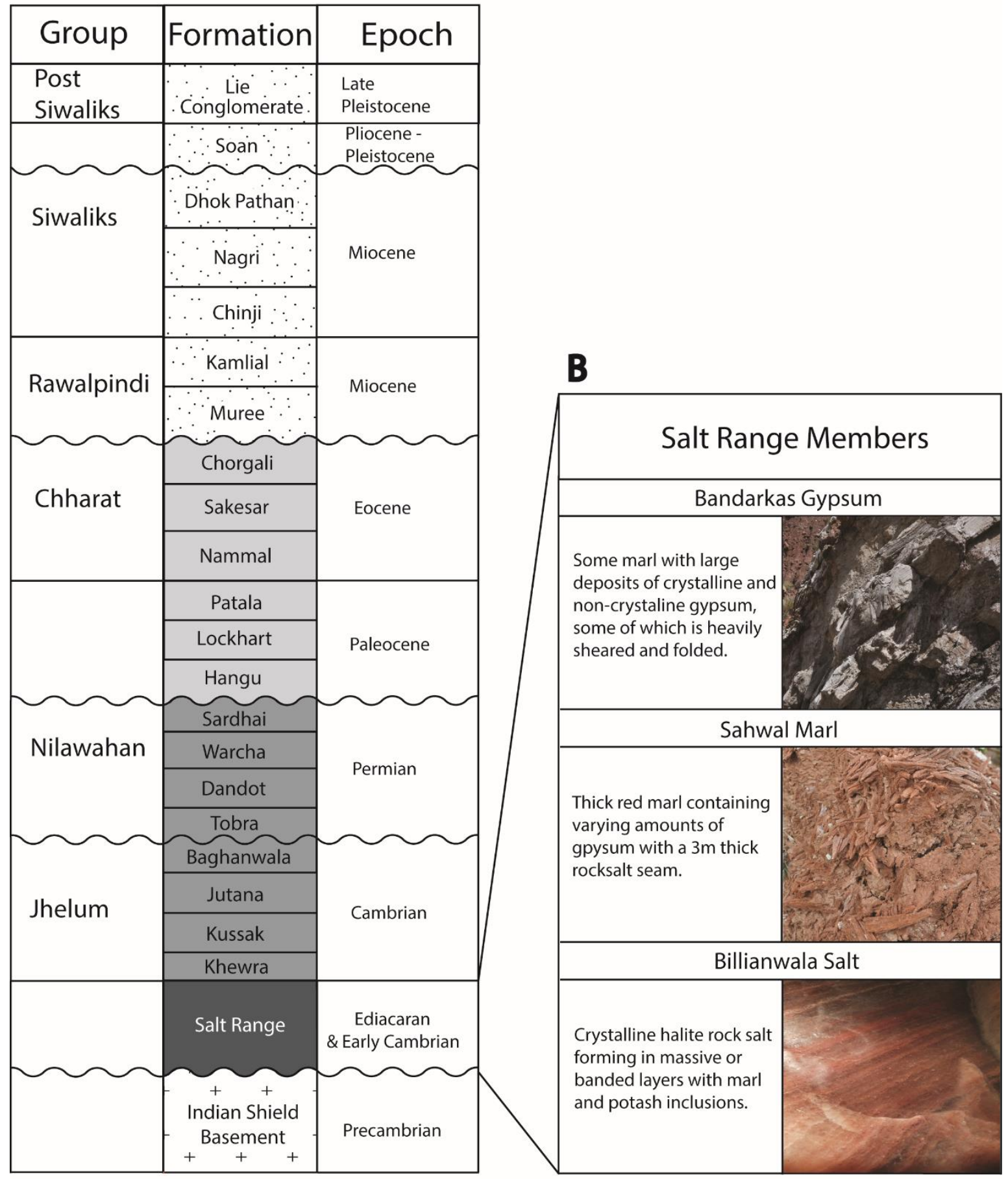

Fig. 2. A) Stratigraphic column of the units within the study area. B) Salt Range Member subdivisions (after Richards et al., 2015) 
https://doi.org/10.5194/gchron-2021-16

Preprint. Discussion started: 28 May 2021

(c) Author(s) 2021. CC BY 4.0 License.

(c) (i)

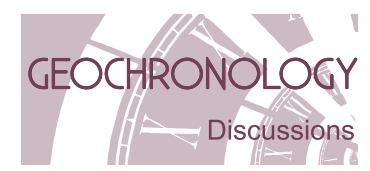

Conformably above this are Cambrian marine sedimentary rocks of the Jhelum Group, predominantly consisting of maroon fine-grained sandstones and shales (Ghazi et al., 2012). These are first unconformably overlain by Permian tillites, 100 sandstones, siltstones, and shales of the Nilawahan Group (Khan et al., 1986), then by Paleocene to Eocene fossiliferous carbonates and shales (Ghazi et al., 2012). Miocene to Quaternary units of the Rawalpindi and Siwaliks Groups form a six $\mathrm{km}$ thick syntectonic molasse resulting from erosion of the forming Himalayas (Fig. 2A) (Grelaud et al., 2003).

Two samples taken from the Billianwala Member of the Salt Range Formation were collected from a mine wall within Khewra Mine (Fig. 1B). A detailed compositional and structural analysis of these samples is presented in Richards et al.

105 (2015).

Sample SRLR-05 was taken from the massive crystalline halite and consists of 95\% pure halite $(\mathrm{NaCl})$ with pink orange inclusions and bands comprised of carnalite $\left(\mathrm{MgCl}_{2} \cdot \mathrm{KCl} \cdot 6 \mathrm{H}_{2} \mathrm{O}\right)$ and polyhalite $\left(2 \mathrm{CaSO}_{4} \cdot \mathrm{MgSO}_{4} \cdot \mathrm{K}_{2} \mathrm{SO}_{4} \cdot \mathrm{H}_{2} \mathrm{O}\right)$ (Fig. $\left.3 \mathrm{~A}\right)$.

Sample SRLR-06 was taken from a thick band of maroon coloured potash marl containing halite boudins adjacent $(8 \mathrm{~m})$ to sample SRLR-05 (Fig. 3B). Predominantly composed of marl, halite, gypsum, potash salts and clay minerals, the sample is

110 highly deformed showing mylonitic fabrics, boudinaged halite and, evidence of partial and total recrystallisation (Fig. 3B) (Richards et al., 2015). As above, polyhalite and carnallite are the dominant potash salt. 
https://doi.org/10.5194/gchron-2021-16

Preprint. Discussion started: 28 May 2021

(c) Author(s) 2021. CC BY 4.0 License.
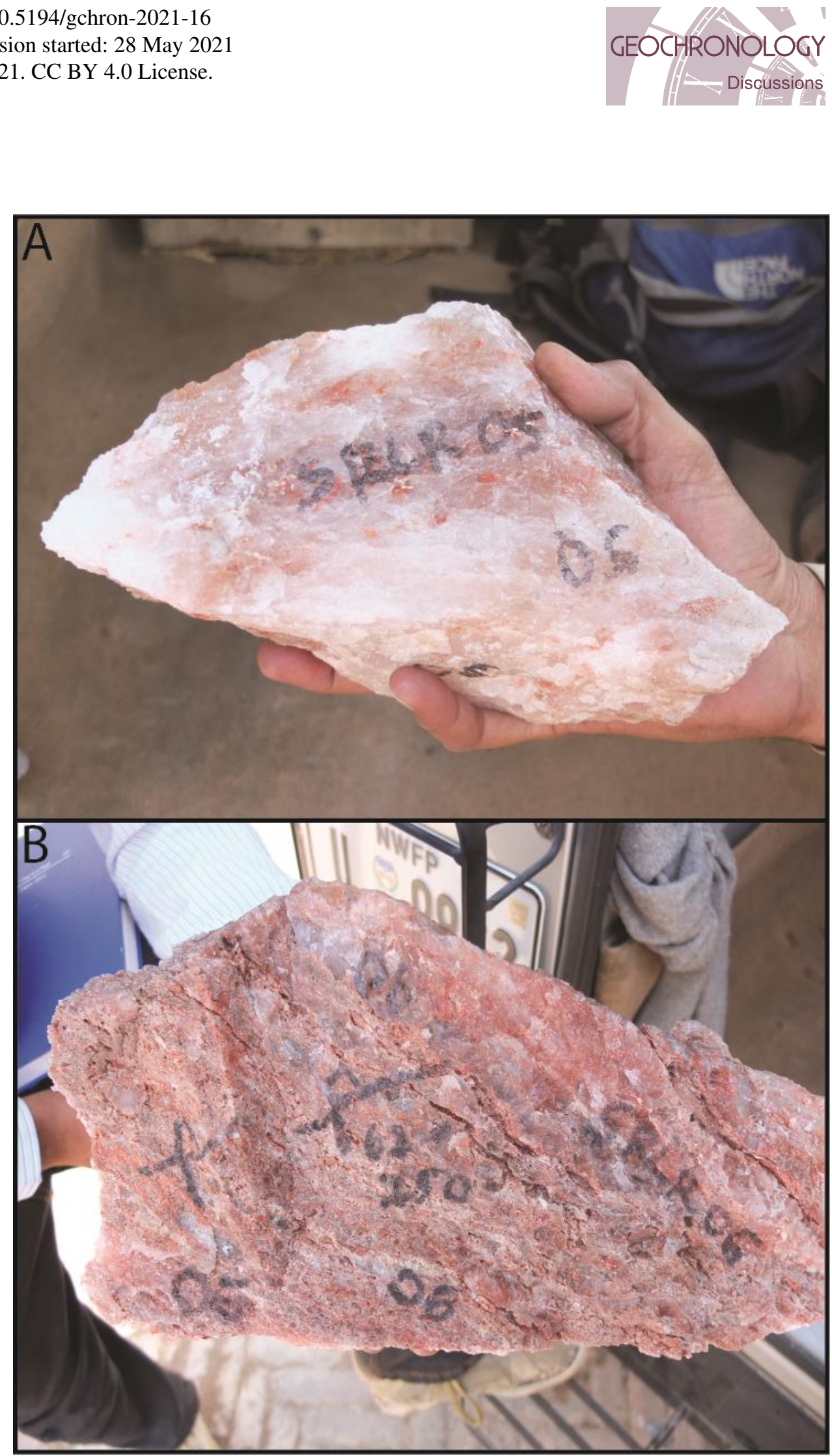

Fig. 3. A) Sample SRLR-06 from Khewra Mine. B) Sample SRLR-05 from Khewra Mine. 
https://doi.org/10.5194/gchron-2021-16

Preprint. Discussion started: 28 May 2021

(c) Author(s) 2021. CC BY 4.0 License.

\section{(c) (1)}

\section{Methodology}

115 Polyhalite grains were separated by gently crushing the sample, then washing for $30 \mathrm{sec}$ in distilled water to dissolve and remove any halite. Halite was carefully removed before irradiation as $\mathrm{Cl}$ produces interference $38 \mathrm{Ar}$ affecting the calculated ages (Esser et al., 1997; Leitner et al., 2013). As polyhalite is hydrous and only semi-soluble the grains do not experience alteration with such short contact when washed (Marcel et al., 2017). Once separated the polyhalite grains were loaded into aluminium disks, $1.9 \mathrm{~cm}$ diameter and $0.3 \mathrm{~cm}$ depth, and bracketed by small wells containing nuetron-fluence monitors. One sample (SRLR06-2.2) underwent irradiation with the Fish Canyon sanidine (FCs) as a neutronfluence monitor (28.294 \pm $0.037 \mathrm{Ma}, 1 \sigma$ error; Renne et al., 2011). All other grains were irradiated with GA-1550 biotite (99.738 $\pm 0.100 \mathrm{Ma}$; $1 \sigma$ error; Renne et al., 2011). The discs were Cd-shielded (to minimize undesirable nuclear interference reactions) and irradiated for $40 \mathrm{~h}$ in the Oregon TRIGA reactor in a central position. The mean J-value computed from standard grains within the small pits is $0.01082100 \pm 0.00001623$ to $0.01086400 \pm 0.00002600$, which is determined as the average and standard deviation of J-values of the small wells. Mass discrimination was monitored using an automated air pipette and provided a mean value of $1.003236( \pm 0.05 \%)$ per dalton relative to an air ratio of $298.56 \pm 0.31$ (Lee et al., 2006). The correction factors for interfering isotopes were $\left({ }^{39} \mathrm{Ar} /{ }^{37} \mathrm{Ar}\right) \mathrm{Ca}=7.60 \times 10-4( \pm 1.2 \%),\left({ }^{36} \mathrm{Ar} /{ }^{37} \mathrm{Ar}\right) \mathrm{Ca}=2.70 \times 10-4( \pm 0.74 \%)$ and $\left({ }^{40} \mathrm{Ar} /{ }^{39} \mathrm{Ar}\right) \mathrm{K}=7.30 \times 10-4$ $( \pm 12.4 \%)$. These ${ }^{40} \mathrm{Ar} /{ }^{39} \mathrm{Ar}$ analyses were conducted at the Western Australian Argon Isotope Facility at Curtin University. The grains were step-heated using a $110 \mathrm{~W}$ Spectron Laser Systems, with a continuous Nd-YAG (IR; $1064 \mathrm{~nm}$ ) laser rastered over the sample for $1 \mathrm{~min}$ to ensure that all the gas has been extracted and a homogenised temperature was reached across the samples. The gas was purified in a stainless steel extraction line using one GP50 and two SAES AP10 getters. Ar isotopes were measured in static mode using a MAP 215-50 mass spectrometer (resolution of $\sim 450$; sensitivity of $4 \times 10-14$ $\mathrm{mol} / \mathrm{V}$ ) with a Balzers SEV 217 electron multiplier. The data acquisition was performed with the Argus programme written by M.O. McWilliams and was run under a LabView environment. The raw data were processed using the ArArCALC

135 software (Koppers, 2002) and ages were calculated using the decay constants recommended by Renne et al. (2011). ${ }^{40} \mathrm{Ar}$ blanks range from $1 \times 10-16$ to $2 \times 10-16 \mathrm{~mol}$ and were monitored every third step; calculated age data are presented with $2 \sigma$ errors.

Contemporaneous step-heating experiments were run using the above methods to determine the diffusion kinetics of polyhalite. Using arrhenius plots, based on arrhenius law calculations describing the first order kinetic loss of a diffusant as a

140 function of temperature, we can determine the closure temperature (Tc) of the mineral system (Dodson, 1973; Reiners et al., 2018). For detailed analytical methods and calculations for measuring diffusion see Reiners et al., 2018.

$$
\ln \left(\frac{D}{a^{2}}\right)=\ln \left(\frac{D_{0}}{a^{2}}\right)+\left(\frac{-E_{a}}{R}\right)\left(\frac{1}{T}\right)
$$


https://doi.org/10.5194/gchron-2021-16

Preprint. Discussion started: 28 May 2021

(c) Author(s) 2021. CC BY 4.0 License.

(c) (i)

$145 \mathrm{R}$ is the gas constant, Ea is the activation energy, $\mathrm{D}$ is the diffusion coefficient, a is the diffusion size, $\mathrm{T}$ is the temperature. Using the linear relationship (Eq. 1.) we can plot the array of step-heating data $\ln \left(\mathrm{D} / \mathrm{a}^{2}\right)$ as a function of inverse temperature to determine Ea and $\mathrm{D}_{0} / \mathrm{a}^{2}$ from the slope and intercept respectively (Reiners et al., 2018). We calculated closure temperature by weighted linear regression using Isoplot 3.7 (Ludwig, 2003) with $\mathrm{D}_{0} / \mathrm{a}^{2}$ calculated assuming spherical geometry and analysed sample size. All results are reported at $2 \sigma$ errors ( $95 \%$ confidence).

\section{Results}

\section{$4.1{ }^{40} \mathrm{Ar} /{ }^{39} \mathrm{Ar}$ age dating}

Polyhalite single crystals, polycrystals and grain aggregates taken from larger samples underwent step-heating ${ }^{40} \mathrm{Ar} /{ }^{39} \mathrm{Ar}$ age dating. A summary of results for all nine samples presented in Table. 1 include calculated plateau ages, isochron ages, K/Ca ratios, and oldest and youngest step ages.

155 Apparent age spectra plots display the apparent ages for each step of the experiment and are calculated representing a percentage of cumulative ${ }^{39} \mathrm{Ar}$ released with the last step resulting in $100 \%{ }^{39} \mathrm{Ar}$ released from the sample. Stacked below each age plot are the K/Ca ratios. Stacked apparent age and K/Ca spectrum plots are presented in Figs. 4 and 5. These results have been separated based on the quality and interpretability of the data with Fig. 4 presenting analytically valid data from which interpretations can be drawn. Erroneous data with high analytical errors that we consider invalid for interpretation are

160 presented in Fig. 5.

${ }^{40} \mathrm{Ar} /{ }^{39} \mathrm{Ar}$ geochronology results are presented with age spectra plots; for geological significance to be assigned to these results the apparent ages and plateau ages should overlap within $2 \sigma$ error confidence. Generally, a plateau age is calculated when at least 3 consecutive steps have overlapping apparent ages and at least $70 \%$ of total ${ }^{39} \mathrm{Ar}$ released from the sample and with mini-plateau age containing between 50 and $70 \%$ of the total ${ }^{39} \mathrm{Ar}$ released. As the calculated ages of all samples only

165 returned one plateau age with significant errors, precise ages of the formation are unable to be derived. However, the qualitative information regarding the minimum age of crystallisation and maximum age of diffusion loss or recrystallization can be derived from the present results (see discussion by Jourdan, 2012). As such the oldest and youngest step ages are presented in Table. 1, with the oldest step age reflecting a minimum age of primary crystallization and the youngest step age reflecting the maximum age of deformation and Ar diffusion loss. 
https://doi.org/10.5194/gchron-2021-16

Preprint. Discussion started: 28 May 2021

(c) Author(s) 2021. CC BY 4.0 License.

(c) (1)

\begin{tabular}{|c|c|c|c|c|c|c|c|c|c|c|c|c|c|c|c|}
\hline Sample & Steps & $\begin{array}{l}\text { Plateau } \\
2 \sigma(\mathrm{Ma})\end{array}$ & Age \pm & $\begin{array}{l}\text { MSW } \\
\text { D }\end{array}$ & $\begin{array}{l}\% \\
{ }^{39} \mathrm{Ar}\end{array}$ & $\mathrm{K} / \mathrm{Ca}$ & & $\begin{array}{l}\text { Inverse } \\
\text { Isochron Age } \\
\pm 2 \sigma(\mathrm{Ma})\end{array}$ & $\begin{array}{l}\text { MSW } \\
\text { D }\end{array}$ & $\begin{array}{l}\text { Youngest } \\
\text { Age } \pm 2 \sigma\end{array}$ & $\begin{array}{l}\text { Step } \\
\text { (Ma) }\end{array}$ & $\begin{array}{l}{ }^{\%} \\
{ }^{39} \mathrm{Ar}\end{array}$ & $\begin{array}{l}\text { Oldest Step } \\
2 \sigma(\mathrm{Ma})\end{array}$ & Age \pm & $\begin{array}{l}\% \\
{ }^{39} \mathrm{Ar}\end{array}$ \\
\hline 05-P2 & 9 & $\begin{array}{l}\text { incalc } \\
\text { ulable }\end{array}$ & & & & 0.82 & \pm 0.0179 & incalculable & & 292.0 & \pm 1 & 24.4 & 380.6 & \pm 0.9 & 8.5 \\
\hline 05-W2 & 7 & $\begin{array}{l}\text { incalc } \\
\text { ulable }\end{array}$ & & & & 0.83 & \pm 0.0209 & incalculable & & 286.3 & \pm 1 & 22.8 & 415.3 & \pm 1.4 & 15.5 \\
\hline $06-1.2$ & 7 & 201.6 & \pm 120.5 & 0.64 & 85.7 & $\begin{array}{l}0.001 \\
7\end{array}$ & \pm 0.0002 & $\begin{array}{ll}32 & \\
2.0 & \\
4 & 178.23\end{array}$ & 0.42 & $\mathrm{~N} / \mathrm{A}$ & - & 17.0 & N/A & - & 14.3 \\
\hline $06-2.1$ & 8 & $\begin{array}{l}\text { incalc } \\
\text { ulable }\end{array}$ & & & & 0.82 & \pm 0.02 & incalculable & & 186.5 & \pm 1.2 & 4.7 & 348.3 & \pm 0.8 & 29.9 \\
\hline $06-2.2$ & 7 & $\begin{array}{l}\text { incalc } \\
\text { ulable }\end{array}$ & & & & $\begin{array}{l}0.004 \\
6\end{array}$ & \pm 0.0002 & incalculable & & N/A & - & 52.0 & N/A & - & 8.7 \\
\hline $06-3.1$ & 9 & $\begin{array}{l}\text { incalc } \\
\text { ulable }\end{array}$ & & & & 0.82 & \pm 0.0152 & incalculable & & 469.9 & \pm 2.3 & 10.4 & 514.0 & \pm 2.6 & 19.5 \\
\hline $06-3.2$ & 9 & $\begin{array}{l}\text { incalc } \\
\text { ulable }\end{array}$ & & & & 0.77 & \pm 0.0167 & incalculable & & 272.3 & \pm 1.5 & 5.7 & 423.6 & \pm 1.6 & 15.6 \\
\hline $06-4.2$ & 7 & $\begin{array}{l}\text { incalc } \\
\text { ulable }\end{array}$ & & & & $\begin{array}{l}0.018 \\
5\end{array}$ & \pm 0.0006 & incalculable & & 61.7 & \pm 14.6 & 49.2 & 618.1 & \pm 92.0 & 5.7 \\
\hline $06-4.2^{\prime}$ & 8 & $\begin{array}{l}\text { incalc } \\
\text { ulable }\end{array}$ & & & & $\begin{array}{l}0.020 \\
9\end{array}$ & \pm 0.0005 & incalculable & & N/A & - & 36.2 & N/A & - & 4.5 \\
\hline
\end{tabular}

Table 1. Polyhalite ${ }^{40} \mathrm{Ar} /{ }^{39} \mathrm{Ar}$ age dating summary of results.

175 No plateau ages are calculated for the apparent age spectra plots in Fig. 4. All three plots (05-P2, 05-W2, 06-2.1) show a stepped diffusion profile of increasing age with cumulative ${ }^{39} \mathrm{Ar}$ released. The initial and final steps in these apparent age plots converge around similar ages representing the youngest and oldest significant ages for their respective samples, these ages are presented in Table. 1. Similarly, the K/Ca ratios form a flat profile indicating simple diffusion with Ar generation from a single domain. 

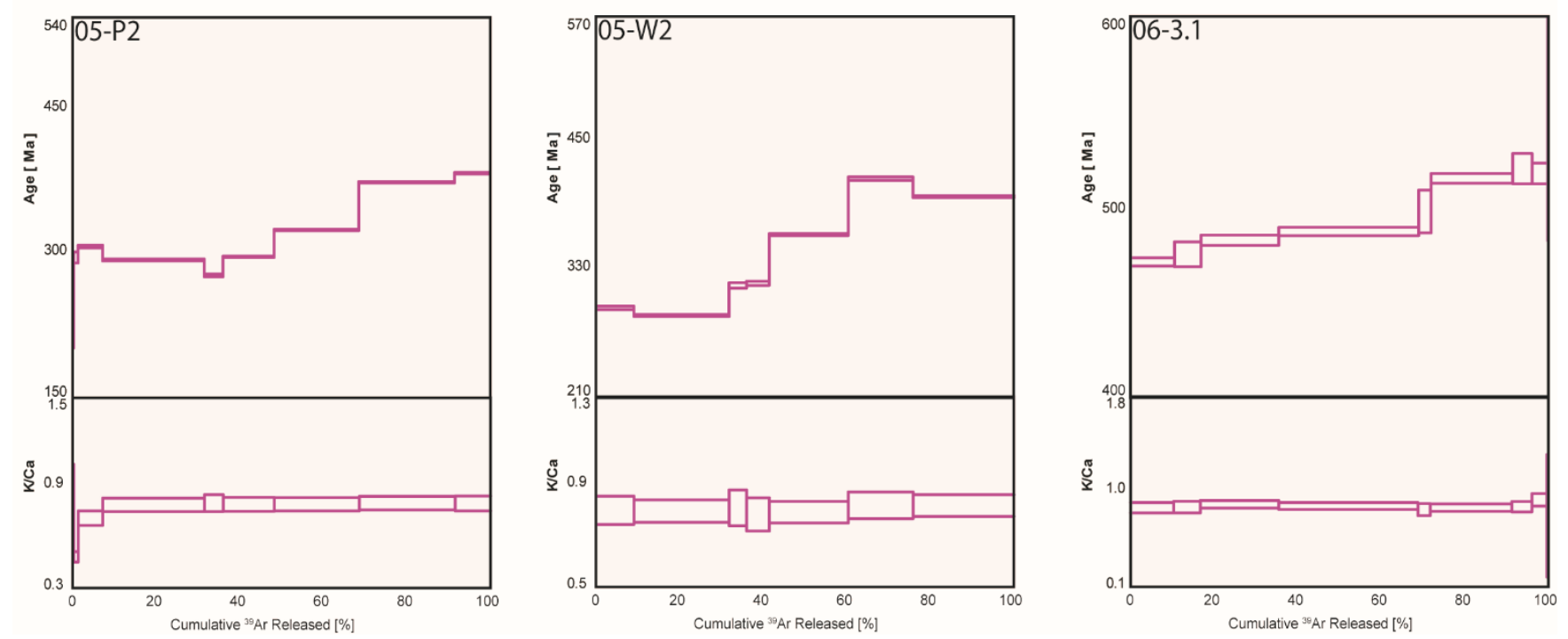

Fig. 4. Combined apparent age spectra and K/Ca plots for samples 05-P2, 05-W2, and 06-3.1. The thickness of individual spectra blocks are indicative of measurement uncertainty.

185 Normally, it is considered unwise to attempt to derive too much information from poor, strongly perturbed ${ }^{40} \mathrm{Ar} /{ }^{\beta 9} \mathrm{Ar}$ age spectra quality data is not considered presentable; however, we have included it here to attempted to derive as much as information as we reasonably could, in part due to the limited ${ }^{40} \mathrm{Ar} /{ }^{39} \mathrm{Ar}$ geochronology data on polyhalite in the literature. Sample 06-1.2 returned a plateau age of $202 \mathrm{Ma}$ with $86 \%{ }^{39} \mathrm{Ar}$ released across seven steps with large analytical uncertainty $( \pm 121 \mathrm{Ma})$ and mean square of weighted deviates (MSWD) of 0.64 . This plateau age is not geologically significant due to the large uncertainty. As no other samples returned plateau ages much of our analysis is limited to the oldest and youngest step ages, however, only ages with relatively small uncertainty are selected. For example, Sample 06-4.2' has a youngest step age of $160 \pm 1330 \mathrm{Ma}$ and oldest step age of $204 \pm 754 \mathrm{Ma}$; neither of these ages hold any meaning so are disregarded and the nearest step age of sufficient precision is selected. These data are presented in Table. 1. 

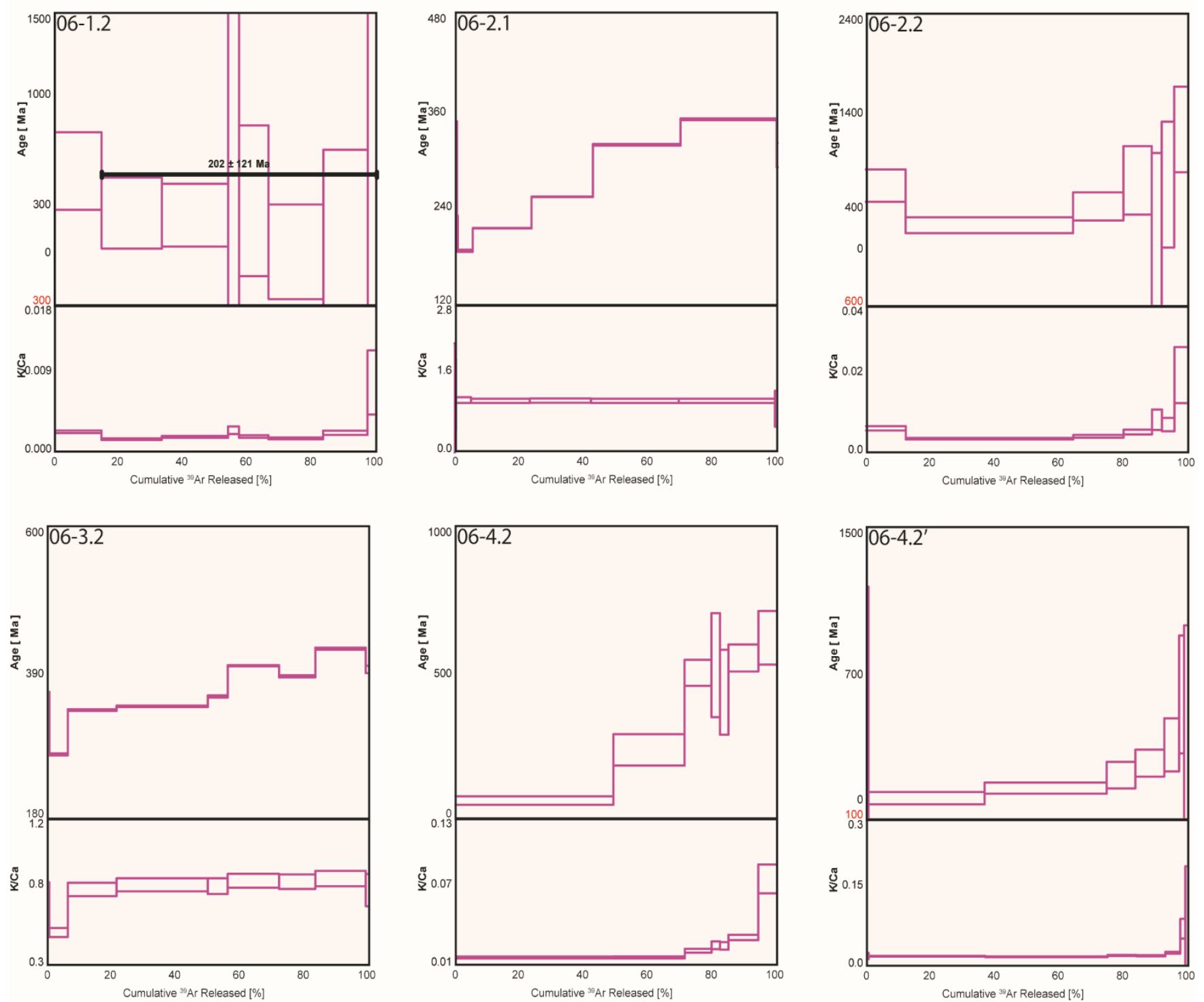

Fig. 5. Combined apparent age spectra and K/Ca plots for samples 06-1.2, 06-2.1, 06-2.2, 06-3.2, 06-4.2, 06-4.2'. The thickness of individual spectra blocks are indicative of measurement uncertainty.

Samples 06-2.1 and 06-3.2 show a stepped diffusion profile of increasing age with cumulative ${ }^{39} \mathrm{Ar}$ released, as presented above. The K/Ca ratios are similarly indicative of single domain diffusion. Samples 06-1.2, 06-2.2, 06-4.2, and 06-4.2' exhibit entirely different profiles with apparent age steps generally trending towards older ages with increasing cumulative ${ }^{39} \mathrm{Ar}$ released and extremely low K/Ca ratios between 0.0017 and 0.02 . Most notably, the analytical error in the data for these samples are extremely large, with the smallest error at $2 \sigma$ being half the apparent age value, 06-4.2': $12.86 \pm 33.11 \mathrm{Ma}$, and 
https://doi.org/10.5194/gchron-2021-16

Preprint. Discussion started: 28 May 2021

(c) Author(s) 2021. CC BY 4.0 License.

(c) (i)

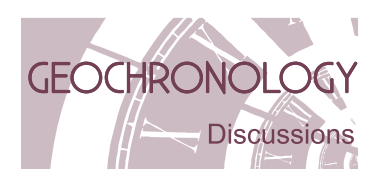

EGU

the largest being greater than three times the apparent age value, 06-1.2: 1070.71 Ma $\pm 3.3 \mathrm{Ga}$ (Table. 1). As a result, any interpretations or conclusions drawn from these data are geologically meaningless.

Samples 05-P2 and 05-W2 show a restricted spread of youngest significant ages (286 and 292 Ma, respectively), oldest significant ages (380 and $415 \mathrm{Ma}$, respectively), and near identical K/Ca ratios ( 0.82 and 0.83 , respectively) (Table. 1). The remaining samples derived from sample SRLR06 show a more varied spread of youngest and oldest ages. Sample 06-4.2' has a youngest significant age of $13 \mathrm{Ma}$ and sample 06-2.2 has an oldest significant age of $677 \mathrm{Ma}$ (Table. 1). Two distinct populations within the samples are identified by plotting the calculated age vs K/Ca ratio (Fig. 6). Samples 06-2.1, 06-3.1, 06-3.2 have ratios between $0.77-0.82$ and are similar to the ' 05 ' samples. The remaining ' 06 ' samples form a second population with drastically smaller $\mathrm{K} / \mathrm{Ca}$ ratios between 0.0017 and 0.02 .

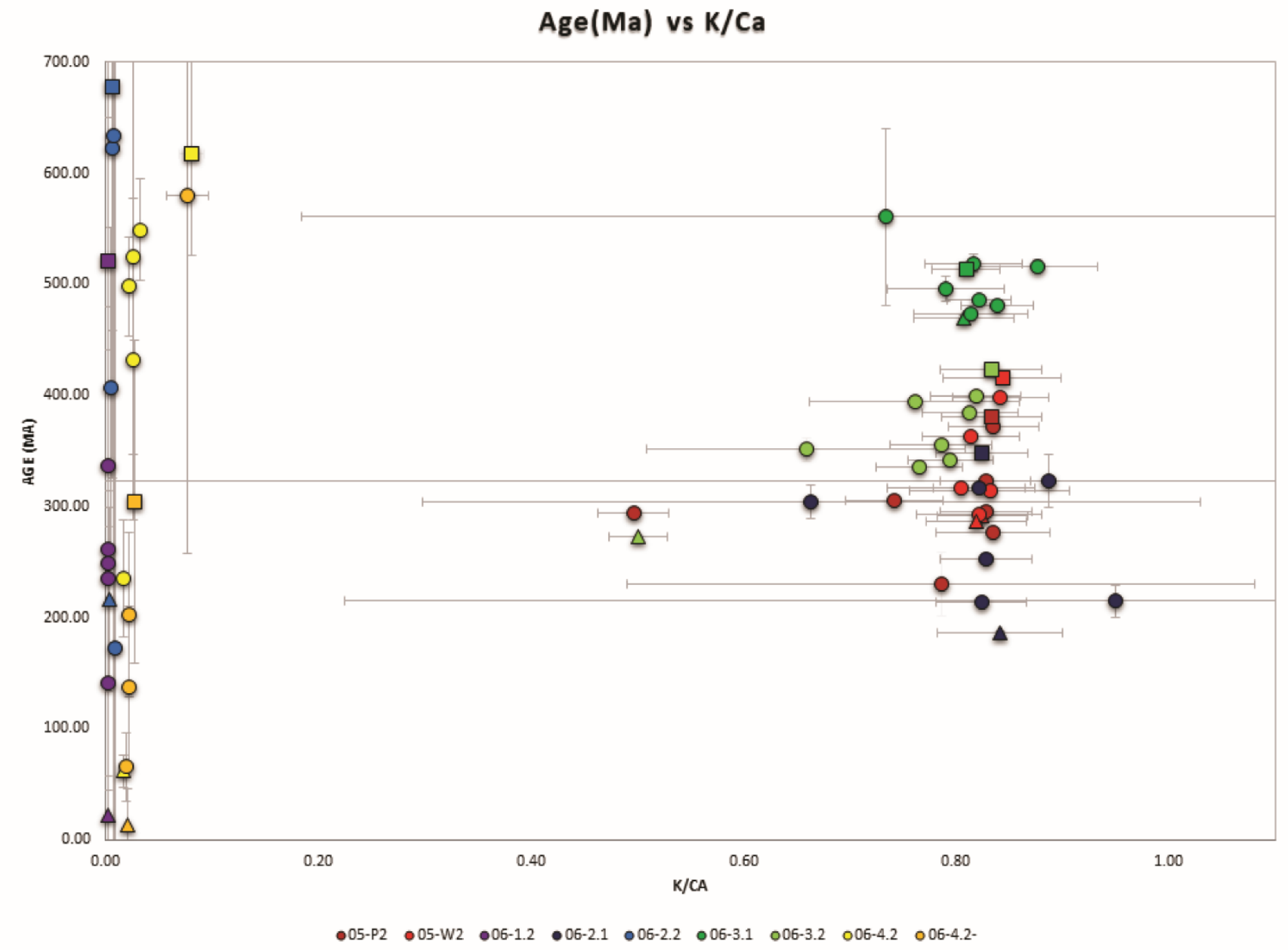

Fig. 6. Apparent age vs K/Ca plot displaying two distinct populations within the samples tested. 
https://doi.org/10.5194/gchron-2021-16

Preprint. Discussion started: 28 May 2021

(c) Author(s) 2021. CC BY 4.0 License.

(c) (1)

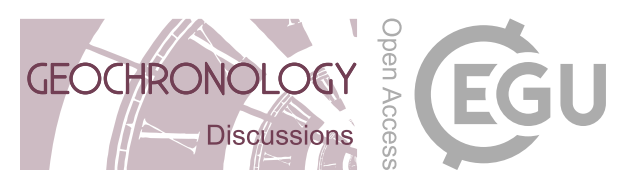

Typically, inverse isochron diagrams are created as a secondary age calculation and to assist with measuring the value of trapped ${ }^{40} \mathrm{Ar} /{ }^{36} \mathrm{Ar}$ (McDougall and Harrison, 1999). Isochron plots of these data are not presented here as they do not add any additional value as most data points plot along the $\mathrm{X}$-axis and do not form a mixing line to allow for age calculation.

\subsection{Closure Temperature}

220 Separate step-heating experiments were performed to determine the closure temperature of Ar in polyhalite. Arrhenius plots measuring diffusion of ${ }^{39} \mathrm{Ar}$ for samples 05 and 06 are presented in Fig. 7.

- Sample 05 returned activation energies (Ea) of $322(+43.3 /-49.1) \mathrm{KJ} / \mathrm{mol}$ and $\mathrm{D}_{0}$ values of 1.33E+10; these values result in a calculated closure temperature (Tc) of ca. $296^{\circ} \mathrm{C}$ for a cooling rate of $10^{\circ} \mathrm{C} / \mathrm{Ma}$ (Fig. 7A).

225 - Sample 06 returned activation energies (Ea) of $284.9(+5.4 /-29.9) \mathrm{KJ} / \mathrm{mol}$ and $\mathrm{D}_{0}$ values of 2.62E+07; these values result in a calculated closure temperature (Tc) of ca. $281{ }^{\circ} \mathrm{C}$ for a cooling rate of $10^{\circ} \mathrm{C} / \mathrm{Ma}$ (Fig. 7B). 
https://doi.org/10.5194/gchron-2021-16

Preprint. Discussion started: 28 May 2021

(c) Author(s) 2021. CC BY 4.0 License.

(c) (i)

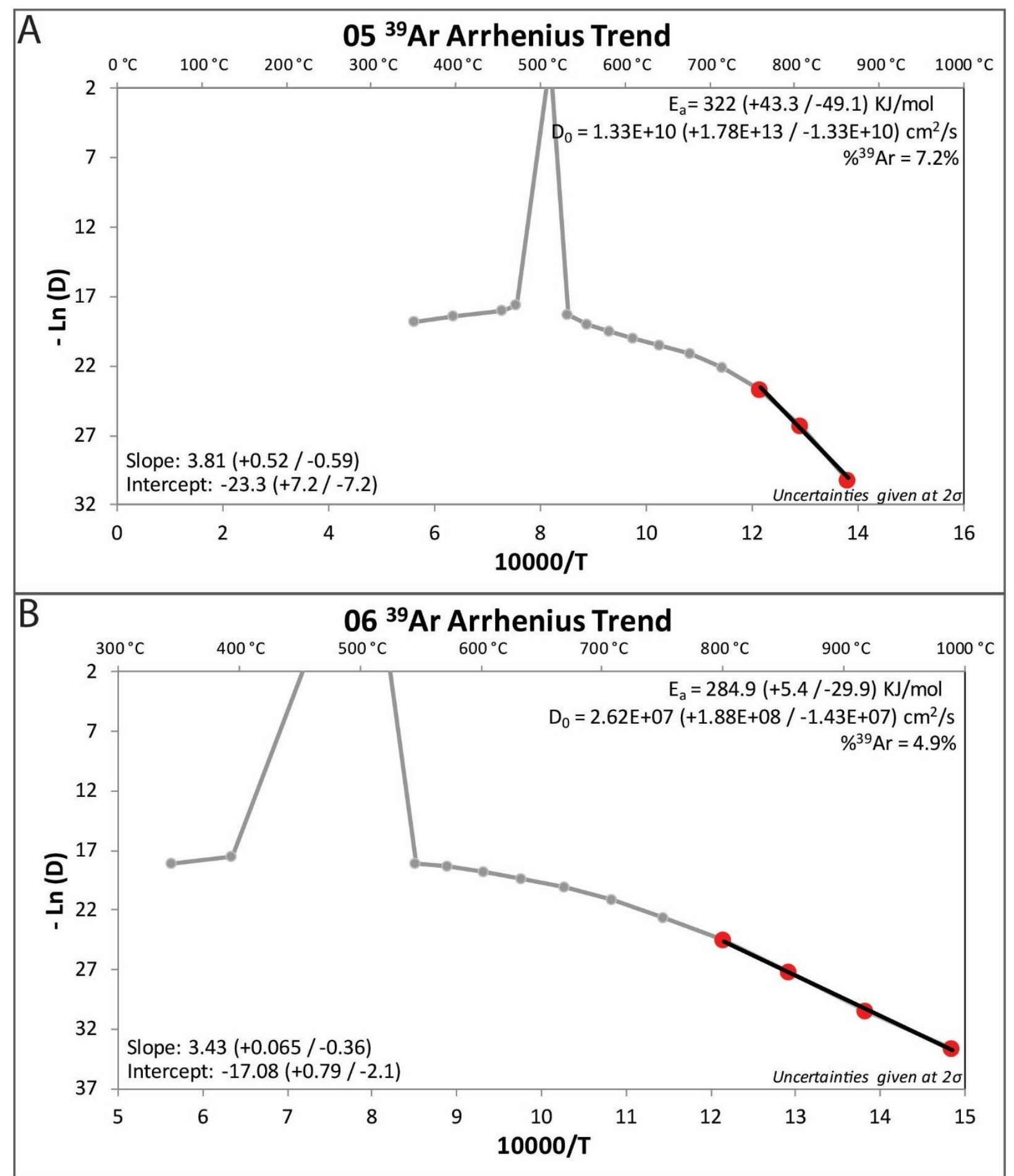

Fig. 7. Arrhenius plot of argon diffusion coefficients calculated from step-heating experiment data against a reciprocal absolute temperature in polyhalite from two sample SRLR05 (A) and SRLR06 (B) 
https://doi.org/10.5194/gchron-2021-16

Preprint. Discussion started: 28 May 2021

(c) Author(s) 2021. CC BY 4.0 License.

(c) (i)

\section{Discussion}

The purpose of this work is using ${ }^{40} \mathrm{Ar} /{ }^{39} \mathrm{Ar}$ geochronology to determine a depositional or resetting age for the polyhalite in the Salt Range Formation as well as establishing the closure temperature for the mineral polyhalite. The Salt Range Formation has an upper age constraint of early Cambrian, from trilobite and brachiopod fossils in the overlaying Khewra

235 Formation. It also rests unconformably over the Precambrian basement of the Indian Shield (Khan et al., 1986). Our step heating experiments did not return plateau ages, with all the samples exhibiting apparent age profiles typical of single domain diffusion; the one sample that did return a plateau age is invalid due to unacceptably high errors.

Of the nine samples that underwent step-heating analysis, six were determined to be of insufficient quality for any interpretation. Samples 06-1.2, 06-2.2, 06-4.2, and 06-4.2' contained significant analytical errors. Coincidentally these 240 samples coincide with the 2nd population of grains in Fig. 6 with K/Ca ratios much lower than the other samples. We suspect the analytical errors associated with these samples may correspond to the overall low K values. Samples 06-2.1 and 06-3.2 also exhibit step-heating profiles typical of single domain diffusion. The lack of convergence of early and late steps to an apparent age of any significance results in vaguely interpretable spectral plots of unknown significance (Fig. 5). Observations of halite boudins within the mylonitic potash marl, from which the '06' samples were taken, indicate that the 245 marl layers acted as fluid flow pathways within the much thicker massive crystalline halite units (Richards et al., 2015). These bands of potash marl have the highest percentage $\mathrm{K}-\mathrm{Mg}$ salts within the formation (Fig. 3B); ultimately this results in a higher likelihood of dissolution, back reaction, altered brine chemistry, and recrystallisation (Warren, 2006). This process of dissolution and recrystallisation may partially or wholly reset the closed K-Ar isotopic system by untrapping the daughter decay products; consequently, the age calculations based on isotope ratios will reflect the younger deformation / recrystallisation age or an incorrectly calculated age between the depositional and recrystallisation ages if dissolution is partial (Jourdan, 2012; McDougall and Harrison, 1999).

\subsection{Diffusion characteristics of polyhalite}

Our experiments on the diffusion parameters for polyhalite have resulted in Ea between $285-322 \mathrm{KJ} / \mathrm{mol}$ and $\mathrm{D}_{0}$ between $2.62 \mathrm{E}+07-1.33 \mathrm{E}+10$. Linear regression of these parameters returned in calculated closure temperatures (Tc) between 281 -

$255296^{\circ} \mathrm{C}$ for a cooling rate of $10^{\circ} \mathrm{C} / \mathrm{Ma}$. Argon diffusion characteristics and Tc for commonly dated minerals are presented in Table 2 below. In comparison to other Ar datable minerals polyhalite sits at the lower end of the closure temperature range but have relatively higher activation energies (Ea). A more detailed list of argon diffusion characteristics can be found in Baxter (2010). 


\begin{tabular}{|c|c|c|c|c|}
\hline Mineral & $\mathbf{E}_{\mathbf{a}}(\mathbf{K J} / \mathbf{m o l})$ & $D_{0}\left(\mathrm{~m}^{2} / \mathrm{s}\right)$ & $\mathrm{TC}(\mathrm{C})$ & Reference \\
\hline Polyhalite & $285-322$ & $\begin{array}{c}2.62 \mathrm{E}+07- \\
1.33 \mathrm{E}+10\end{array}$ & $281-296$ & This study \\
\hline Langbeinite & $178-184.1$ & $1.00 \mathrm{E}-31$ & 200 & $\begin{array}{l}\text { Lippolt \& Oesterle (1977) } \\
\text { \& Renne et al. (2001) }\end{array}$ \\
\hline Plagioclase & $155.3-178 . .4$ & $\begin{array}{c}1.34 \mathrm{E}-04-9.08 \mathrm{E}- \\
06\end{array}$ & $225-300$ & Cassata (2009) \\
\hline Biotite & 197.2 & 7.50E-06 & 300 & $\begin{array}{c}\text { Dodson et al. (1973) \& } \\
\text { McDougall and Harrison } \\
\text { (1999) }\end{array}$ \\
\hline Muscovite & 263.7 & $2.30 \mathrm{E}-04$ & $405-425$ & Harrison (2009) \\
\hline Hornblende & 276.3 & $6.00 \mathrm{E}-06$ & $480-580$ & Harrison (1982) \\
\hline Tourmaline & $505-815$ & $\begin{array}{c}1.65 \mathrm{E}-15-5.95 \mathrm{E}- \\
27\end{array}$ & $492-637$ & Thern et al. (2020) \\
\hline Pyroxene & $371.0-379.2$ & $\begin{array}{c}1.36 \mathrm{E}-04-5.73 \mathrm{E}- \\
02\end{array}$ & $600-800$ & Cassata (2011) \\
\hline
\end{tabular}

Table 2. Argon diffusion parameters and closure temperature (Tc) for commonly dated minerals

\subsection{Thermal stability and dehydroxilation of polyhalite}

Dehydroxilation in a mineral occurs during heating above a mineral specific temperature resulting in the loss of the hydroxyl group $(\mathrm{OH})$. This phenomenon is pertinent to incremental heating experiments involving hydrous minerals, which may undergo irreversible structural and morphological phase changes inherently altering the active diffusion mechanism and subsequently derived kinetics (Cassata and Renee, 2013; Gaber et al., 1988; Harrison et al., 2009; Lee et al., 1991; Thern et al., 2020). As such, volume diffusion kinetics derived from minerals undergoing phase changes may be measuring the original mineral, a new phase or mineral, or a composite of both depending on when this phase change occurs.

270 Polyhalite is known to dehydrate with the following first order reaction between $280^{\circ}$ to $360^{\circ}$ at pressures between 0.5 and 6.1 bars from heating experiments (Nathans, 1963). 


$$
\mathrm{K}_{2} \mathrm{Ca}_{2} \mathrm{Mg}\left(\mathrm{SO}_{4}\right)_{4} \cdot 2 \mathrm{H}_{2} \mathrm{O} \rightarrow \mathrm{K}_{2} \mathrm{CaMg}\left(\mathrm{SO}_{4}\right)_{3}+\mathrm{CaSO}_{4}+2 \mathrm{H}_{2} \mathrm{O}
$$

275 Further, thermal experimentation by Wollmann et al. (2008) identified the dehydration characteristics of polyhalite and its analogues with dehydration onset at $255{ }^{\circ} \mathrm{C}$ and peaking at $343^{\circ}{ }^{\circ} \mathrm{C}$ for polyhalite and onset between $185-311{ }^{\circ} \mathrm{C}$ for the various analogues. The specific thermal decomposition reactions observed by Fischer et al. (1996) and expanded upon by Xu et al. (2016) show polyhalite dehydrates into anhydrite, two solid solution langbeinite-type phases with different $\mathrm{Ca} / \mathrm{Mg}$ ratios, and water vapor between $237-343{ }^{\circ} \mathrm{C}$. This is accompanied by a $5.8 \%$ mass loss associated with water vapor removal (Xu et al., 2016).

$$
\mathrm{K}_{2} \mathrm{Ca}_{2} \mathrm{Mg}\left(\mathrm{SO}_{4}\right)_{4} \cdot 2 \mathrm{H}_{2} \mathrm{O} \rightarrow \mathrm{K}_{2} \mathrm{Ca}_{x} \mathrm{Mg}_{2-x}\left(\mathrm{SO}_{4}\right)_{3}+\mathrm{K}_{2} \mathrm{Ca}_{y} \mathrm{Mg}_{2-y}\left(\mathrm{SO}_{4}\right)_{3}+\mathrm{CaSO}_{4}+2 \mathrm{H}_{2} \mathrm{O}
$$

Upon heating to $646{ }^{\circ} \mathrm{C}$ the two langbeinite phases combine to a single-phase triple salt (Xu et al, 2016).

$$
\mathrm{K}_{2} \mathrm{Ca}_{x} \mathrm{Mg}_{2-x}\left(\mathrm{SO}_{4}\right)_{3}+\mathrm{K}_{2} \mathrm{Ca}_{y} \mathrm{Mg}_{2-y}\left(\mathrm{SO}_{4}\right)_{3} \rightarrow \mathrm{K}_{2} \mathrm{CaMg}\left(\mathrm{SO}_{4}\right)_{3}
$$

The polyhalite unit cell parameters have been established by Wollman et al. (2008) and the variation of these as a function of temperature by $\mathrm{Xu}$ et al. (2016). These thermal experiments are conducted at atmospheric conditions or with variations to pressure so it is unknown whether polyhalite decomposition will differ from these results as minerals have displayed lower phase transformation temperatures in vacuo (Vasconcelos et al., 1994c). While the combined effect of geological conditions (temperature, lithospheric pressure, water volume) on these reactions is unknown, the dihydroxylation temperature of polyhalite presented here, $237-343{ }^{\circ} \mathrm{C}$, is around our calculated Tc $281-296{ }^{\circ} \mathrm{C}$. This indicates polyhalite is Ar retentive below its phase transformation temperature in vacuo, which impedes accurate calculation of diffusion kinetics and closure temperatures with this method. As such, our calculated diffusion characteristics and closure temperatures are only semiquantitative, representing a first attempt at measuring the diffusion kinetics of polyhalite. Conducting hydrothermal diffusion experiments would serve as a great alternative and may alleviate the hydroxilation issue. Hydrothermal diffusion experiments increase the thermal stability range of a mineral before decomposition onset allowing for higher analytical temperatures to be reached (e.g. Baldwin et al., 1990; Giletti, 1974; Harrison et al., 2009). Unfortunately, this approach was not possible during this study. It would make an ideal continuation of this work on expanding our understanding of the diffusion parameters of polyhalite and its applicability to future geochronological work. 
https://doi.org/10.5194/gchron-2021-16

Preprint. Discussion started: 28 May 2021

(c) Author(s) 2021. CC BY 4.0 License.

\subsection{Age Interpretations}

While it is impossible to determine the initial deposition age of an evaporite sequence with no known lower boundary without a plateau age from ${ }^{40} \mathrm{Ar} /{ }^{39} \mathrm{Ar}$ geochronology, we can derive an oldest age of precipitation or alteration. Samples 063.1 returned an oldest apparent step age of $514 \pm 3 \mathrm{Ma}$; we attribute this age to represent a minimum age, probably not so far from the time at which this polyhalite grain precipitated. This age may represent the depositional age of precipitation from a surface brine; however, we believe it is more representative of precipitation during lithification as polyhalite is most commonly a secondary evaporite occurring as a back reaction (Warren, 2006).

The oldest apparent step ages for samples 05-P2 and 05-W2 (381 \pm 1 Ma and $415 \pm 1$ Ma respectively) are significantly lower than the youngest age of the Salt Range Formation of ca. 514 Ma from our step heating experiment on sample 06-3.1 or from the stratigraphically constrained base Cambrian age. As such, these samples must have experienced conditions capable of significantly resetting the K/Ar decay system. For the majority of minerals this occurs when the mineral is heated beyond its closure temperature. However, as polyhalite is a chemical precipitate, percolating fluids of the correct composition are capable of dissolving and re-precipitating new minerals (Warren, 2006). As polyhalite forms from precipitation or alteration rather than magmatic crystallisation it is most likely these minerals formed well below the closure temperature, effectively locking both $\mathrm{K}$ and Ar with insignificant post-formation diffusion. For these samples, whether alteration is thermally derived or purely recrystallisation, we can establish that the oldest apparent step ages represents a minimum age at which these new polyhalite grains first formed. The youngest significant ages for these two samples constrain the age of termination of these alteration processes. The youngest significant ages $-286 \pm 1$ Ma for sample 05 -W2 and $292 \pm 10 \mathrm{Ma}$ for sample 05-P2 - provide a maximum age for the recrystallization of a second generation of polyhalite, or for an heating event that partially reset the first generation of polyhalite.

Placed in geological context these dates correspond with the time of the unconformity between the middle Cambrian sequence of the Baganwalla Formation and the early Permian glacio-fluvial to shallow marine sediments of the Tobra Foramtion (Khan and Khan, 1979; Khan et al., 1986). It is tempting to suggest that these ages reflect recrystallisation by circulating meteoric fluids during this non-depositional time, possibly with glacial meteoric water having infiltrated the evaporites around the time of rifting and break-up of the northern Gondwana border.

However, collision between the Indian and Eurasian plates is ongoing with crustal movement rates estimated to be $\sim 3 \mathrm{~mm} / \mathrm{y}$ (Satyabala et al. 2012). Numerous <4.9 Mw earthquakes in the region and neotectonic features within the Salt Range Thrust indicating that the location where these samples were collected is currently active (Haq et al. 2013). Combining this information with the youngest calculated step age of $62 \pm 15 \mathrm{Ma}$, and the observation of the extreme microscopic deformation in the mylonite (Richards et al. 2015), we can speculate on the nature of the interaction between the Ar system and recrystallization. 
https://doi.org/10.5194/gchron-2021-16

Preprint. Discussion started: 28 May 2021

(c) Author(s) 2021. CC BY 4.0 License.

(c) (i)

1. Stress-induced recrystallisation experienced by these samples is only ever partial, with intracrystalline domains preserved that remain unrecrystallised, else only the most recent deformation events to reset the system should be recorded in the Ar system.

2. If total recrystallisation has occurred, but the Ar system isn't fully reset, then recrystallisation retains Ar despite the host crystal structure's recrystallisation. This would suggest little to no fluid is present during recrystallisation.

3. Deformation events resulting in deformation and recrystallisation may have heterogeneously affected the Salt Range Formation with some grains (e.g. those in boudins), preserving different microstructural and isotopic records.

4. The samples analysed were only recrystallised at this age while others may have experienced more recent deformation resetting its closed Ar system but were not analysed.

Fitting with most historic ${ }^{40} \mathrm{Ar} /{ }^{39} \mathrm{Ar}$ age dating studies of potash salts, the results presented in this study display significantly younger ages of formation than their known upper limit of base Cambrian age. We suggest that later deformation events are the primary cause of this open system behaviour, rather than a result of prolonged thermally-induced diffusion. Located within a tectonically active setting, with evidence for recent $(0.4-2.1 \mathrm{Ma})$ to currently active movement nearby, and hosted in, or close to evaporate mylonites, these samples have experienced, at least partial, grain boundary migration and recrystallisation (Yeats et al., 1984; Jaswal et al., 1997; Haq et al., 2013). However, microstructural work by Richards (2021) ascertain that even in heavily deformed evaporites, earlier microstructures are preserved, suggesting that these intracrystal domains may retain radiogenic Ar and preserve older ages.

\section{Conclusions}

The ${ }^{40} \mathrm{Ar} /{ }^{39} \mathrm{Ar}$ step heating geochronology performed on these nine samples was partially successful. Despite being unable to determine significant plateau ages to reliably date the evaporites of the Salt Range Formation, we can speculate on a few key points regarding the deformation history of these evaporites. The combined apparent age spectra and K/Ca plots for samples 05-P2, 05-W2, and 06-3.1 exhibit profiles consistent with pure diffusion kinetics from a single domain and are interpreted to represent the following:

- The oldest step age, $514 \pm 3 \mathrm{Ma}$, for sample 06-3.1 is a maximum age for diagenetic precipitation. As polyhalite is rarely formed as a primary evaporite, we believe this likely represents the age at which backreactions during lithification have precipitated polyhalite.

- The youngest and oldest step ages: $286 \pm 1 \mathrm{Ma}-415 \pm 1 \mathrm{Ma}$ for sample 05-W2 and $292 \pm 1 \mathrm{Ma}-380 \pm 1 \mathrm{Ma}$ for sample 05-P2 are interpreted to represent a complex mixing age between diagenetic formation in the Cambrian and partial resetting as a result of stress induced recrystallisation. Both the oldest and youngest step ages for samples 05-W2 and 05-P2 occur during the unconformity between the Cambrian Baghanwala Formation and the Permian Tobra Formation (Fig. 2A). Circulating meteoric fluids during this non-depositional 
time and continuing during the Permian may have contributed to the dissolution and recrystallisation of the Salt Range Formation evaporites. We believe the complete physical reconstitution of the formation due to extensive deformation during the Cenozoic exhibits a greater control in resetting the $\mathrm{K} / \mathrm{Ar}$ system and thus is more likely. Diffusion experiments on two samples from the Salt Range, Pakistan have resulted in closure temperatures between 281 and $296^{\circ} \mathrm{C}$ at a cooling rate of $10^{\circ} \mathrm{C} / \mathrm{Ma}$. To our knowledge this is the first experiment to determine a closure temperature for the mineral polyhalite. Due to polyhalite dehydroxilation and its impact on Ar diffusion kinetics these experimentally derived parameters are only semi-quantitative and must be taken with a grain of salt. As such, they serve only as a first pass on polyhalite diffusion kinetics and cannot be used for geochronological works with any precision.

Hydrothermal diffusion experiments on polyhalite make an ideal next step in this work by assessing the diffusion parameters of the mineral at higher temperatures before the thermal decomposition begins. Similarly understanding the timing between phase transformation and Ar diffusion in the new crystal structure will be essential in understanding Ar degassing mechanics in both polyhalite and langbeinite. Furthermore, developing our understanding of the link between polyhalite recrystallisation and Ar diffusion is key to the application of Ar geochronology to deformed evaporite units.

The practical use of ${ }^{40} \mathrm{Ar} /{ }^{39} \mathrm{Ar}$ geochronology on polyhalite is in its infancy. Despite the difficulty of using the mineral as a geochronometer, further understanding of its diffusion kinetics will clarify its potential for use in geological interpretations and develop our understanding of the thermal history of K-bearing evaporite formations.

\section{Acknowledgements}

This work was funded by the Australian Research Council grant \#DP120101560. ASC is funded by ARC future fellowship \#FT120100340. As well as the Frederick A. Sutton Memorial Grant as part of the American Association of Petroleum Geologists Foundation Grants-In-Aid program. The authors would like to thank the National Centre of Excellence in Geology, University of Peshawar and the Pakistan Academy of Sciences for their support and hospitality as well as the

385 Khewra Mine Deputy Manager of mining Mr Irfam Ahmad and Chief Engineer Mr Bakhtiar Ali for allowing us access and sampling within the Khewra Mine.

\section{Bibliography}

Aldrich, L. T., Nier, A. O., 1948. Argon 40 in potassium minerals, Phys. Rev., 74, 876-877

Baldwin, S, Harrison, T \& Gerald, J 1990, 'Diffusion of 40 Ar in metamorphic hornblende', Contributions to Mineralogy 390 and Petrology, vol. 105, no. 6, pp. 691-703.

Baxter, E.F. Diffusion of Noble Gases in Minerals. Reviews in Mineralogy and Geochemistry ; 72 (1): 509-557. doi: https://doi.org/10.2138/rmg.2010.72.11 
https://doi.org/10.5194/gchron-2021-16

Preprint. Discussion started: 28 May 2021

(c) Author(s) 2021. CC BY 4.0 License.

(c) (i)

Brookins, D. G., Register, J. K., Krueger, H. W. (1980). "Potassium-argon dating of polyhalite in southeastern New Mexico." Geochimica et Cosmochimica Acta 44(5): 635-637.

395 Cassata, W. S, Renne, P. R. Shuster, D. L. (2009). "Argon diffusion in plagioclase and implications for thermochronometry: A case study from the Bushveld Complex, South Africa." Geochimica et Cosmochimica Acta 73(21): 6600-6612.

Cassata W. S. and Renne P. R. (2013) Systematic variations of argon diffusion in feldspars and implications for thermochronometry. Geochim. Cosmochim. Acta 112, 251-287.

Cassata, W. S., Renne, P. R., Shuster, D. L. (2011). "Argon diffusion in pyroxenes: Implications for thermochronometry and mantle degassing." Earth and Planetary Science Letters 304(3): 407-416.

Davis, D. M., Lillie, R. J., 1994, Changing mechanical response during continental collision: Active examples from the foreland thrust belts of Pakistan. Journal of Structural Geology, 16, 21-34.

Dodson, M. H. (1973) Closure temperature in cooling geochronological and petrological systems. Contributions to Mineralogy and Petrology 40(3), 259-274.

405 Esser, R.P., McIntosh, W.C., Heizler, M., Kyle, P., 1997. Excess argon in melt inclusions in zero-age anorthoclase feldspar from Mt. Erebus, Antarctica, as revealed by the 40Ar39Ar method.

Fischer, S., et al. (1996). "The Thermal Decomposition of Polyhalite K2SO4 · MgSO4 · 2 CaSO4 - 2 H2O." Crystal Research and Technology 31(1): 87-92.

Gaber L. J., Foland K. A. and Corbato' C. E. (1988) On the significance of argon release from biotite and amphibole during 410 40Ar/39Ar vacuum heating. Geochim. Cosmochim. Acta 52, 2457-2465.

Ganguly, J. and C. M. Gramaccioli (2002). Diffusion kinetics in minerals: Principles and applications to tectonometamorphic processes. Energy Modelling in Minerals, Mineralogical Society of Great Britain and Ireland. 4: 0.

Gee, E. R. 1989, Overview of the geology and structure of the Salt Range, with observations on related areas of northern Pakistan. Special Papers of the Geological Society of America, 232, 95-112.

415 Gee, E. R., 1980, Pakistan geological Salt Range series: Direc ᄀtorate of Overseas Surveys, United Kingdom, for the Govaernment of Pakistan, and Geological Survey of Pakistan, 6 sheets, scale 1:50,000.

Ghazi, S., Mountney, N. P., Butt, A. A., Sharif, S., 2012, Stratigraphic and palaeoenvironmental framework of the Early Permian sequence in the Salt Range, Pakistan. Journal of Earth System Science, 121.

Giletti, B. J. (1974) Studies in diffusion I: Ar in phologopite mica. In: Hofmann AW et al (eds) Geochemical transport and 420 kinetics. Carnegie Publ 634:107-115

Haq, A. U.; Choudhary, M. N.; Burg, J. P.; Majid, Ch. M., 2013. Geology, Seismicity and Seismic Risks Assessment of Eastern Salt Range, Punjab - Pakistan. Pakistan Journal of Science . Mar2013, Vol. 65 Issue 1, p63-68. 6p.

Hardie, L. A., 1984, Evaporites: Marine or non-marine? American Journal of Science, v. 284, p. 1279-1301.

Hardie, L. A., 1990. The roles of rifting and hydrothermal CaCl2 brines in the origin of potash evaporites: A hypothesis. 425 American Journal of Science, v. 290, p.43-106. 
https://doi.org/10.5194/gchron-2021-16

Preprint. Discussion started: 28 May 2021

(c) Author(s) 2021. CC BY 4.0 License.

(c) (i)

Hardie, L.A., 1991. On the Significance of Evaporites. Annual Review of Earth and Planetary Sciences 19, 131-168.

Harrison, T.M. (1982) Diffusion of 40Ar/39Ar in hornblende. Contrib Mineral Petrol 78:324-331

Harrison, T. M., Célérier, J., Aikman, A. B., Hermann, J., Heizler, M. T. (2009). "Diffusion of 40Ar in muscovite." Geochimica et Cosmochimica Acta 73(4): 1039-1051.

430 Jaswal, T. M., Lillie, R. J., Lawrence, R.D., 1997, Structure and evolution of the northern Potwar deformed zone, Pakistan. American Association of Petroleum Geologists Bulletin, 81, 308-328.

Jaumé, S. C., \& Lillie, R. J., 1988, Mechanics of the Salt-Range Potwar Plateau, Pakistan: A fold and thrust belt underlain by evaporites. Tectonics, 7, 57-71.

Khan, M. A., \& Khan, M. J., 1979, Petrography of The Baghanwala Formaion, Khewra Gorge, Khewra, Jhelum District, 435 Punjab, Pakistan. Geological Bulletin (University of Peshawar Vol 12. 2.

Khan, M. A., Ahmed, R., Raza, H. A., and Kemal, A., 1986, Geology of petroleum in Kohat-Potwar depression, Pakistan. AAPG Bulletin, 70, 396-414.

Koppers, A.A.P., 2002. ArArCALC—software for 40Ar/39Ar age calculations. Computers \& Geosciences 28, 605-619.

Kovalevych, V. M., Marshall, T., Peryt, T. M., Petrychenko, O. Y., Zhukova, S. A., 2006, Chemical composition of seawater

440 in Neoproterozoic: Results of fluid inclusion study of halite from Salt Range (Pakistan) and Amadeus Basin (Australia). Precambrian Research, 144.

Lee J. K. W., Onstott T. C., Cashman K. V., Cumbest R. J. and Johnson D. (1991) Incremental heating of hornblende in vacuo: Implications for 40Ar/39Ar geochronology and the interpretation of thermal histories. Geology 19, 872-876.

Lee, J.Y.,Marti, K., Severinghaus, J.P., Kawamura, K., Yoo, H.S., Lee, J.B., Kim, J.S., 2006. A redetermination of the 445 isotopic abundance of atmospheric Ar. Geochimica et Cosmochimica Acta 70, 4507-4512.

Leitner, C., Neubauer, F., Genser, J., Borojevic-Sostaric, S., Rantitsch, G. (2014). "40Ar/39Ar ages of crystallization and recrystallization of rock-forming polyhalite in Alpine rocksalt deposits." 378(1): 207-224.

Léost, I., Féraud, G., Blanc-Valleron, M. M., Rouchy, J. M. (2001). "First absolute dating of Miocene Langbeinite evaporites by 40Ar/39Ar laser step-heating: [K2Mg2(SO4)3] Stebnyk Mine (Carpathian Foredeep Basin)." Geophysical Research 450 Letters 28(23): 4347-4350.

Lillie, R. J., Johnson, G. D., Yousuf, M., Zamin, A. S. H. \& Yeats, R. S., 1987, Structural development within the Himalayan foreland fold-and-thrust belt of Pakistan. In: Beaumont, C. \& Tankard, A. J. (Eds). Sedimentary Basins and Basin Forming Mechanisms. Memoirs of the Canadian Society of Petroleum Geologists, 12, 379-392.

Lippolt, H. J. and Oesterle, F. P. (1977). "Argon retentivity of the mineral langbeinite." Naturwissenschaften 64(2): 90-91.

455 Ludwig, K.R. (2003) Isoplot 3.00: a geochronological toolkit for Microsoft Excel. Berkeley Geochronological Centre Special Publications 4.

Marcel, B., Yuncong, C. L., Guodong, L., Zhenli, H., (2017). Characterizing Polyhalite Plant Nutritional Properties. Agri Res \& Tech: Open Access J. 2017; 6(3): 555690. DOI: 10.19080/ARTOAJ.2017.06.555690. 
https://doi.org/10.5194/gchron-2021-16

Preprint. Discussion started: 28 May 2021

(c) Author(s) 2021. CC BY 4.0 License.

(c) (i)

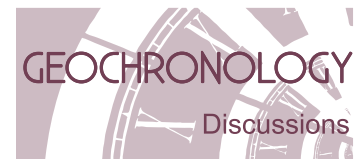

McDougall, I. and T. M. Harrison (1999). Geochronology and thermochronology by the 40Ar/39Ar method. Oxford, Oxford

University Press.

Molnar, P. and P. Tapponnier (1977). "The Collision between India and Eurasia." Scientific American 236(4): 30-41.

Nathans, M. W. (1963). "The Dehydration of Polyhalite" The Journal of Physical Chemistry 67(6): 1248-1249.

Pilot, J.P. Blank, K-Ar Bestimmungen yon Saltgestein des Zchsteins, Z. Angew. Geol., 13, 661-662, 1967

Powell, C. M., \& Conaghan, P. J. (1973). Plate tectonics and the Himalayas. Earth and Planetary Science Letters, 20(1), 1-

12. https://doi.org/10.1016/0012-821X(73)90134-9

Reiners, P.W., Carlson, R.W., Renne, P.R., Cooper, K.M., Granger, D.E., McLean, N.M., Schoene, B., 2017. Geochronology and thermochronology.

Renne, P. R., Sharp, W. D., Montaez, I. P., Becker, T. A., \& Zierenberg, R. (2001). 40Ar/39Ar dating of Late Permian evaporites, southeastern New Mexico, USA. Earth and Planetary Science Letters, 193(3-4), 539547.

https://doi.org/10.1016/S0012-821X(01)00525-8

Renne, P. (2006). Progress and Challenges in K-Ar and 40Ar/39Ar Geochronology. The Paleontological Society Papers, 12, 47-66. doi:10.1017/S1089332600001340

Renne, P.R., Balco, G., Ludwig, K.R., Mundil, R., Min, K., 2011. Response to the comment by W.H. Schwarz et al. on "Joint determination of K-40 decay constants and Ar-40*/K-40 for the Fish Canyon sanidine standard, and improved accuracy for Ar-40/Ar-39 geochronology” by PR Renne et al. (2010). Geochimica et Cosmochimica Acta 75, 5097-5100.

Renne, P. R., Warren D. Sharp, Isabel P. Montañez, Tim A. Becker, Robert A. Zierenberg. (2001). "40Ar/39Ar dating of Late Permian evaporites, southeastern New Mexico, USA." Earth and Planetary Science Letters 193(3): 539-547.

Renne, P.R., Swisher, C.C., Deino, A.L., Karner, D.B., Owens, T.L., DePaolo, D.J., 1998. Intercalibration of standards, absolute ages and uncertainties in 40Ar/39Ar dating. Chemical Geology 145, 117-152.

480 Richards, L. (2021). Evaporite Detachments and their Control on Fold-Thrust Belt Deformation (Ph.D. Thesis). University of Adelaide.

Richards, L., King, R. C., Collins, A. S., Sayab, M., Khan, M. A., Haneef, M., Morley, C. K., Warren, J.. (2015). "Macrostructures vs microstructures in evaporite detachments: An example from the Salt Range, Pakistan." Journal of Asian Earth Sciences 113: 922-934.

485 Satyabala, S. P., Zhaohui, Y., Roger, B., 2012, Stick-slip advance of the Kohat Plateau in Pakistan. Nature Geoscience, 5. Schindewolf, D.H. \& Seilacher, A. (1955) "Burlage Zur Kenntnis des Kambriams in der Salt Range (Pakistan)”, Abh, Akd. Wiss. Litt., Mainz, 10, p.466

Thern, E. R., Blereau, E., Jourdan, F., Nelson, D. R. (2020). "Tourmaline 40Ar/39Ar geochronology and thermochronology: Example from Hadean-zircon-bearing siliciclastic metasedimentary rocks from the Yilgarn Craton." Geochimica et 490 Cosmochimica Acta 277: 285-299. 
https://doi.org/10.5194/gchron-2021-16

Preprint. Discussion started: 28 May 2021

(c) Author(s) 2021. CC BY 4.0 License.

(c) (1)
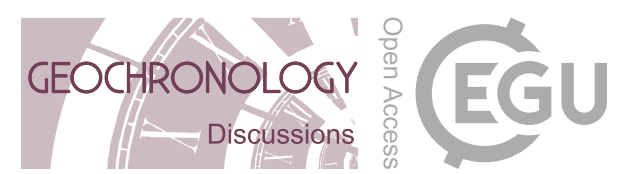

Vasconcelos P. M., Wenk H.-R. and Echer C. (1994c) In-situ study of the thermal behavior of cryptomelane by high-voltage and analytical electron microscopy. Am. Mineral. 79, 80-90.

Warren, J.K., 2006, Evaporites: Sediments, Resources and Hydrocarbons. Springer, 3300 AA Dordrecht, The Netherlands.

Wollmann, G., Freyer, D. \& Voigt, W. Polyhalite and its analogous triple salts. Monatsh Chem 139, 739-745 (2008).

495 https://doi.org/10.1007/s00706-007-0835-7

Wojtowicz, A., Hryniv, S.P., Peryt, T.M., Bubniak, A., Bubniak, I. \& Bilonizhka, P.M. 2003. K/Ar Dating of the Miocene potash salts of the Carpathian Foredeep (West Ukraine): application to dating of tectonic events. Geologica Carpathia, 54, 243-249.

Xu, H., Guo, X., and Bai, J. (2016) Thermal behavior of polyhalite: a high-temperature synchrotron XRD study. United 500 States: N. p., Web. doi:10.1007/s00269-016-0842-5. 125-135.

Yeats, R. S., Khan, S., Akhtar, M., 1984, Late Quaternary deformation of the Salt Range of Pakistan. Geological Society of America Bulletin, 95. 